\title{
Meta
}

Journal des traducteurs

Translators' Journal

\section{A Methodological Proposal for the Study of Semantic Functions across Languages}

\section{Belén Labrador De La Cruz}

Volume 49, numéro 2, juin 2004

URI : https://id.erudit.org/iderudit/009357ar

DOI : https://doi.org/10.7202/009357ar

Aller au sommaire du numéro

Éditeur(s)

Les Presses de l'Université de Montréal

ISSN

0026-0452 (imprimé)

1492-1421 (numérique)

Découvrir la revue

Citer cet article

Labrador De La Cruz, B. (2004). A Methodological Proposal for the Study of Semantic Functions across Languages. Meta, 49(2), 360-380.

https://doi.org/10.7202/009357ar
Résumé de l'article

Après une brève révision des principaux courants de pensée et des modèles grammaticaux dans l'histoire des Études Comparées, nous présentons une méthode d'analyse appropriée aux études descriptives fondées sur un corpus. Nous avons utilisé un " corpus comparable " pour une recherche sur une fonction sémantique, la quantification, et sur son expression dans deux langues, l'anglais et l'espagnol. Les différentes phases du processus sont expliquées et un sommaire des résultats est exposé. Le but final de l'article est de contribuer au renforcement de la discipline grâce à l'apport de résultats sur une paire de langues et à celui d'une méthodologie qui peut être appliquée à des champs sémantiques différents et à des paires de langues. 


\title{
ÉTUDES TERMINOLOGIQUES ET LINGUISTIQUES
}

\section{A Methodological Proposal for the Study of Semantic Functions across Languages}

\author{
BELÉN LABRADOR DE LA CRUZ \\ University of León, León, Spain \\ dfmblc@unileon.es
}

\section{RÉSUMÉ}

Après une brève révision des principaux courants de pensée et des modèles grammaticaux dans l'histoire des Études Comparées, nous présentons une méthode d'analyse appropriée aux études descriptives fondées sur un corpus. Nous avons utilisé un «corpus comparable» pour une recherche sur une fonction sémantique, la quantification, et sur son expression dans deux langues, l'anglais et l'espagnol. Les différentes phases du processus sont expliquées et un sommaire des résultats est exposé. Le but final de l'article est de contribuer au renforcement de la discipline grâce à l'apport de résultats sur une paire de langues et à celui d'une méthodologie qui peut être appliquée à des champs sémantiques différents et à des paires de langues.

\begin{abstract}
After a brief revision of the major currents of thought and grammatical models in the history of CS (Contrastive Studies), a method of analysis suitable for corpus-based descriptive studies across languages is presented and discussed in this paper. As an alternative to translation corpora, the use of comparable corpora is advocated and put into practice in a large-scale research on a particular semantic function, quantification, and its expression in two languages, English and Spanish. The different phases of the process are explained and a summary of achievements is provided. The ultimate purpose of the paper is to contribute to the strengthening of the discipline by offering new results about one pair of languages and by suggesting a methodology that can be broadly applied to different semantic fields and pairs of languages.
\end{abstract}

\section{MOTS-CLÉS/KEYWORDS}

contrastive studies (CS), comparable corpora, methodology, quantification, semantic functions

\section{Introduction}

The method of analysis proposed and advocated here has been tested in a large-scale research that deals with the expression of a semantic field, quantification, in two languages, English and Spanish. This paper is concerned with the description of the different phases of the analysis and also aims at explaining and justifying the decisions taken at each stage.

The methodology suggested is adequate for empirical contrastive studies that make use of computerized corpora as a source of data and focus on meaning and 
how that meaning is realised at different levels of language, especially lexicogrammar. Let us first outline some of the tenets of the prevailing linguistic models used in CS and some of the methodological tendencies, upon some of which the present paper draws.

\section{Review of contrastive models}

In the forties and fifties, much more emphasis was placed on contrasting languages rather than on comparing them. Whorf foresaw the importance of a new linguistic discipline that was starting to take shape at that time:

Much progress has been made in classifying the languages of the earth into genetic families, each having descended from a single precursor, and in tracing such developments through time. The result is called "comparative linguistics." Of even greater importance for the future technology of thought is what might be called "contrastive linguistics." This plots the outstanding differences among tongues - in grammar, logic and general analysis of experience (Whorf 1941:240).

At the beginning, the structuralist framework of American Descriptivism, especially the work of Bloomfield (1933) and some derived currents like taxonomic grammar and tagmemics or the so-called Slot-and-Filler Method, had a strong impact on the first contrastivists, the most relevant of which are Fries (1945) and Lado (1957). They focus on the relationship between the elements of word classes that occupy a 'slot' in a sentence and their syntactic functions or 'fillers.' Their works are usually broad descriptions of very clear-cut levels of analysis: inventories of sounds and their rules, alphabets, morphologies (derivation and inflection), syntax and lexis (forms, meanings and distribution of words). The third element that sets the ground for the contrast is the formal correspondence, which means that the elements to be contrasted occupy the same slot in both languages; what these related elements have in common is their grammatical function in parallel sentences.

A second model leans on the work of Chomsky (1957), and his two basic ideas: a) grammars have to be sufficiently formal and explicit to generate sentences by means of rules and $b$ ) the surface structure of sentences derives from the deep structure through a series of transformations such as movements, substitutions, ellipsis, etc. Krzeszowski $(1979,1990)$, the main representative of this model, compares and contrasts the linguistic elements across languages during the process of generation and bases comparison upon congruence (Krzeszowski 1971:81), that is, the fact that two sentences of different languages may diverge in their superficial appearance but converge in a single and identical deep structure, which is considered to be universal.

A third model also has universality as one of its main tenets; however, unlike the second model, it does not conceive formal universals but some universal semantic categories. It was Fillmore (1968) who developed case grammar out of the transformational model. The latter did not distinguish among the different semantic functions of the same grammatical category, e.g. in the room, towards the moon, on the next day, in a careless way, with a sharp knife and by my brother were all classified as prepositional phrases by transformational grammar but they have different thematic roles: situation, direction, time, manner, instrument and agent respectively. The term 'case' is used to identify the semantic-syntactic relation, which is universal, whereas the term 'case form' is kept to denote the expression of a case relation in a particular 
language (Fillmore 1968:21-24). So case becomes the tertium comparationis. Di Pietro (1971) applies this model based on case grammar to contrastive analysis.

A fourth group comprises some authors from the field of Translation Studies who deal with theoretical matters that concern CS. They consider that all levels of language contribute to confer the whole meaning of the text and they establish the relationship between the message in the two languages by means of equivalence. Their notions of equivalence diverge; some of them, like Nida (1964) and Catford (1965) take a taxonomic view, some others a communicative perspective, for example, Neubert (1985), Rabadán (1991) and Neubert \& Shreve (1992), and some others take a relativist outlook on equivalence as is the case of Reiss and Vermeer (1984), for whom the translation skopos or purpose is predominant and Toury (1980, 1995), for whom the notion of equivalence is subject to the target cultural polysystem. The aim of the communication, the context and the cultural factors, which are implicit in the message, are taken into account. These approaches are based on semantic and functional criteria, which are most useful in CS. The relationship between Translation Studies and CS has been explicitly indicated by many authors. Chesterman argues that the equivalence must be of similarity and not of identity and that

the approach usually taken in Translation Theory focuses on divergent similarity and that usually taken in Contrastive Analysis on convergent similarity. That is, a translation starts with a single phenomenon and derives others from it which retain a relation of similarity with the original; whereas a contrastive analysis starts with two different phenomena which are already assumed to contain some features of similarity (Chesterman 1998:15).

It is also worth mentioning a last group who have received a strong impact from the methods and techniques used by corpus linguistics in the last decades. These authors advocate the use of corpora for empirical research on pairs of languages. The work of many of them is described in volumes of articles edited by Filipovic (1970), Fisiak (1973-), Chitoran (1976), and most recently Aijmer, Altenberg \& Johassson (1996), Jaszczolt \& Turner (1996), Johansson \& Oksefjell (1998), Salkie, Aijmer and Barlow (1999-), etc.

The work presented in this paper is inspired by the ideas of the last two groups. The functional models of translation provide a framework that gives priority to meaning. The notion of equivalence - a similar meaning that is conveyed in the two languages by similar or different resources - acts as the element in common, on which comparison is based. On the other hand, the models based on corpora provide the assets of data, tools and techniques for empirical research on the real use of languages.

\section{Approach and directionality}

The approach followed here is functional in the Hallidayan sense, who argues that the structure of a language evolves and varies as time goes by according to the communicative needs, so the interest of the linguist must lie not so much on the system (elements and rules of a language) but on how this system is used on the basis of particular functions: 
Every text - that is, everything that is said or written - unfolds in some context of use; furthermore, it is the uses of language that, over tens of thousands of generations, have shaped the system. Language has evolved to satisfy human needs; and the way it is organised is functional with respect to these needs (Halliday 1985/ 1994:xiii).

This paper is also in line with some other of his insights like his idea of delicacy as the level or amount of detail and his idea of lexicogrammar, which Sinclair (1991:104) calls 'structure.' Some influence can also be traced back to other authors for whom the concept of functions is crucial, Bondarko (1991), Dik (1989) and Alarcos (1982) who are, as well as Halliday and Sinclair, outside the field of CS and Chesterman (1998) who is a contrastivist. The research described in the present paper takes one "functional-semantic field in an abstract paradigmatic space of a language system" (Bondarko 1991), quantification, as the tertium comparationis or third element of the comparison. Quantity is perceived as a meaning shared by the two languages involved in the study, English and Spanish, hence it becomes the starting point of the research, as suggested by Chesterman (1998):

Contrastive functional analysis starts from perceived similarities of meaning across two or more languages, and seeks to determine the various ways in which these similar or shared meanings are expressed in different languages (Chesterman 1998:1).

The functional approaches are usually interested in paradigmatic (choice) rather than syntagmatic (chain) relations; the latter is associated with generativism. They prefer to look for the sets of options available, which may belong to different levels of the language: lexis, syntax, morphology, etc. But there is another way of looking at the chains of elements without seeking to investigate the processes by which meanings are embodied into forms, without being generative. Sinclair (1991:108) and corpus linguists in general argue that the majority of text is made of the occurrence of common words in common multi-word patterns, or in slight variants of those patterns. The present study builds on both types of influences, thus focusing both on paradigmatic and syntagmatic relations.

Some other authors refer to the directionality of descriptive studies, regardless of their contrastive nature. For example, Louhivaara (1998) claims that "There are basically two methods by which two languages A and B can be contrasted. We may choose some universal category such as 'time' or 'agent' as a tertium comparationis and find out how that category is realized in the two languages. Alternatively, we may start from a category of A and see how that category is realized in $\mathrm{B}$, and/or vice versa" (Louhivaara 1998:145). Unlike this classification, where the starting point is always a category or function, Bondarko (1991:8) states that a language can be described by starting out either from the function or from the form, or even changing course at a particular stage; therefore he classifies the grammatico-functional description of languages as follows:

- semasiological descriptions, which work from form to meaning (from media to functions)

- onomasiological descriptions, which work from meaning to form (from functions to media)

- descriptions based on the combination of the two previous directions at different stages of the analysis 
The present study belongs to the third of these types as it combines both directions. It starts from a function or semantic field, quantification, and then looks for the resources (the quantifiers) in each language to express that function, that is, the first step makes the description onomasiological. The following step is to describe the way these resources behave in their real use and the variety of functions they realize, which means that the description is semasiological at a second stage. But the study does not conclude here. After presenting the series of functions identified, each is associated with the range of structures (the collocational patterns of all the quantifiers studied) that are used to express them, which turns the description into onomasiological again. The two languages are described in a parallel way at the first and second stages; only the third stage is explicitly contrastive but the previous phases are necessary to reach contrast and they yield independent results that are useful for other non-contrastive purposes.

\section{Data}

A distinction must be made between the first stage - onomasiological - and the two other stages concerning the sources of data. For the first stage, a list of resources that express quantification was compiled using a number of English and Spanish grammars - Quirk et al (1989), Downing et al (1992), Berry (1997) and Biber et al (1999) and Bello (1981), Alarcos (1994), Matte Bonn (1995) and Bosque et al (1999) respectively, as well as our own intuition and the opinion of several native informants. Then, these quantifiers constituted the search words in the corpus, that is, these elements led to their different meanings and uses during the second stage, semasiological. The third stage fed on all the data gathered during the second stage.

The data used for the second and third stages of the research came from a comparable corpus made up of two monolingual corpora in English and Spanish. We use the term 'comparable' here in the sense of "original texts in two or more languages which share certain features (typically, texts are from the same genre or subject domain)" (Salkie 1997:305), not in the sense given by other authors, as corpora composed of original and translated texts in the same language (Baker 1995:234). These terms to name the different types of corpora are still fluctuating. 'Parallel corpora' might be another name to refer to the corpus used in this study as they are sometimes said to be composed only of original texts - "parallel texts, i.e., authentic material in the two languages, selecting texts that are maximally equivalent on as many levels as possible" (Louhivaara 1998:145) but at other times they are said to be composed of both original texts and their translations - they are even called "the Rosetta stone of modern corpus linguistics" (McEnery \& Oakes, 1996:211). We can see then that "the term 'parallel' is often used for both types" (Johansson 1998:271).

The comparable corpus used for this study does not exactly "consist of original texts in each language matched by criteria such as time of composition, type of author, intended audience, etc." (Johansson 1998:272). The corpus used here is actually two monolingual corpora that are not matched, that are completely independent from each other, so much so that they have been compiled and belong to two different institutions or companies absolutely unrelated, and yet, they are compatible in terms of quantity and quality - similar number of words and similar range of contents - and they have been chosen to be used for the same research. 
The aim was to study the real use of quantifiers in general language. That is the reason why original texts, without 'translationese' features, were needed and why two large corpora, with a wide variety of textual types, genres, subjects, registers and media were selected. They were Cobuild's Bank of English ${ }^{1}-$ one of the most prestigious English corpora - and RAE's CREA ${ }^{2}$ - undoubtedly the most important Spanish corpus. Only those subcorpora that represent British English and Peninsular Spanish were consulted, which account for more than 42 million words in English and 49 million words in Spanish.

\section{Methodology}

Apart from the three main stages of the whole research based on the function-form directionality, which have been mentioned above, the corpus-based model of analysis that was proposed and used in the study was divided into four main sets of procedures, which bear some similarities with James' (1980:63) two-staged method: description and comparison and Krzeszowski's (1990:35) three-stepped method: description, juxtaposition and comparison. Our four sets of procedures are as follows: First, the selection of quantifiers which were the key words to search for in the corpus, second, the description of these quantifiers according to the data found, third, the juxtaposition of these data around functions and finally the contrast proper. Prior to these processes, it was necessary to decide on which type of quantification the empirical research would focus, as a broad classification of different quantifications had been outlined (Labrador de la Cruz 2000) and the type selected was indefinite quantification.

\subsection{Process of selection}

The two steps of this phase are:

A) Elaborate a list of English and Spanish indefinite quantifiers and search for their frequency rates in CREA and the Bank of English.

B) Apply a statistical formula that would permit the study of the smallest but still sufficiently representative number of occurrences. As the population of concordances to study was generally too large, it was necessary to take a sample of a reduced number for each quantifier. However, the frequency rates varied considerably among the different quantifiers, and so it was not possible to study a fixed number of occurrences for all quantifiers. Taking 300 out of 90,000 did not seem to be as equally representative as taking 300 out of 500, for instance. The following formula was applied in order to ascertain how many concordances should be analysed in each case.

$$
n=\frac{N}{(N-1) E^{2}+1}
$$

where $\mathrm{n}$ is the sample, $\mathrm{N}$ the population and $\mathrm{E}$ the estimative error. Thus, for example, the word none, which occurs 3,029 times in COBUILD, was studied in 353 of its 3,029 cases because:

$$
n=\frac{3,029}{(3,029-1) \cdot 0.05^{2}+1} ; \quad n=\frac{3,029}{8.57} ; \quad n=353.44
$$


Decimals were rounded as they usually are. For decimals higher than 50, a whole number was added; for those lower than 50, they were simply omitted. The tables below show the list of quantifiers studied, along with their total number of occurrences in the corpus and the samples taken after the application of the formula. The quantifiers were divided into seven groups, according to the characteristics given below and they run parallel in the two languages.

Negative quantifiers generally express lack of quantity.

TABLE 1

Selection of negative quantifiers in English and Spanish

\begin{tabular}{|lrr||lrr|}
\hline $\begin{array}{l}\text { English negative } \\
\text { quantifiers }\end{array}$ & Total ner. & Sample & $\begin{array}{l}\text { Spanish negative } \\
\text { quantifiers }\end{array}$ & Total ner. & Sample \\
\hline neither & 2,347 & 342 & na & 220 & 142 \\
\hline no & 91,524 & 398 & ná & 42 & 38 \\
\hline nobody & 3,548 & 360 & nada & 37,019 & 396 \\
\hline none & 3,029 & 353 & nadie & 15,492 & 390 \\
\hline noone & 22 & 21 & ningún & 10,239 & 385 \\
\hline no-one & 3,923 & 363 & ninguna & 8,966 & 383 \\
\hline nothing & 12,523 & 388 & ningunas & 27 & 25 \\
\hline nowhere & 1,020 & 288 & ninguno & 2,655 & 348 \\
\hline & & & ningunos & 11 & 10 \\
\hline
\end{tabular}

Universal quantifiers indicate the totality of a quantity in a concrete universe, restricted, on many occasions, by adjectives, relative clauses, non-finite clauses, etc.

TABLE 2

Selection of universal quantifiers in English and Spanish

\begin{tabular}{|lrr||lrr|}
\hline $\begin{array}{l}\text { English universal } \\
\text { quantifiers }\end{array}$ & Total ner. & \multicolumn{1}{c|}{ Sample } & $\begin{array}{l}\text { Spanish universal } \\
\text { quantifiers }\end{array}$ & Total ner. & Sample \\
\hline all & 117,836 & 399 & ambas & 3,446 & 358 \\
\hline both & 20,518 & 392 & ambos & 6,862 & 378 \\
\hline each & 18,221 & 391 & cada & 32,947 & 395 \\
\hline every & 19,363 & 392 & tó & 15 & 14 \\
\hline everybody & 4,309 & 366 & toa & 15 & 14 \\
\hline everyday & 717 & 257 & toas & 4 & 4 \\
\hline everyone & 6,724 & 378 & toda & 23,971 & 393 \\
\hline everything & 9,779 & 384 & todas & 24,059 & 393 \\
\hline everywhere & 1,410 & 312 & todo & 83,053 & 398 \\
\hline & & & todos & 46,882 & 397 \\
\cline { 4 - 7 } & & & toos & 15 & 14 \\
\cline { 4 - 7 } & & & tós & 0 & 0 \\
\hline
\end{tabular}


Existential quantifiers refer to the existence of some quantity as opposed to absence and totality.

TABLE 3

\section{Selection of existential quantifiers in English and Spanish}

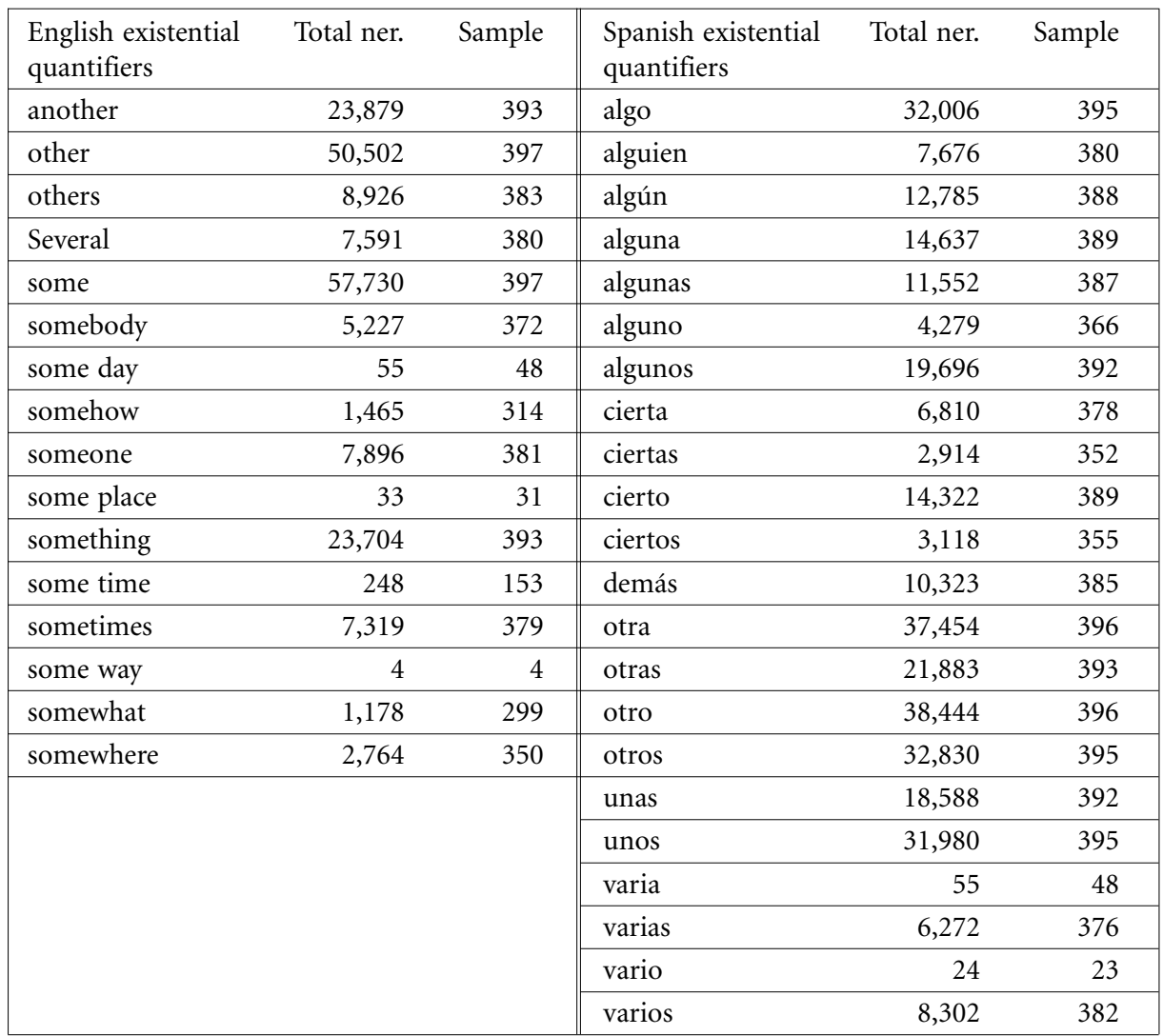

Proportional quantifiers are divided into multal, paucal and relational. Proportional multal quantifiers express a high amount of something, higher than the assumed norm along a scale. 
TABLE 4

Selection of multal quantifiers in English and Spanish

\begin{tabular}{|c|c|c|c|c|c|}
\hline $\begin{array}{l}\text { English multal } \\
\text { quantifiers }\end{array}$ & Total ner. & Sample & $\begin{array}{l}\text { Spanish multal } \\
\text { quantifiers }\end{array}$ & Total ner. & Sample \\
\hline bags & 1,103 & 294 & a destajo & 74 & 63 \\
\hline galore & 88 & 72 & cantidad & 5,331 & 372 \\
\hline good deal & 356 & 189 & cantidades & 1,383 & 310 \\
\hline great deal & 1,212 & 301 & horrores & 260 & 158 \\
\hline heap & 253 & 155 & la tira & 92 & 75 \\
\hline heaps & 92 & 75 & mansalva & 23 & 22 \\
\hline lashings & 38 & 35 & mogollón & 95 & 77 \\
\hline load & 1,020 & 288 & montón & 1,190 & 300 \\
\hline loads & 1,054 & 290 & montones & 271 & 162 \\
\hline lot & 21,275 & 393 & mucha & 5,785 & 374 \\
\hline lots & 2,978 & 353 & muchas & 13,205 & 388 \\
\hline many & 30,417 & 395 & muchísima & 257 & 157 \\
\hline mass & 1,764 & 326 & muchísimas & 373 & 193 \\
\hline masses & 312 & 176 & muchísimo & 1,556 & 318 \\
\hline much & 36,510 & 396 & muchísimos & 334 & 182 \\
\hline myriad & 99 & 80 & mucho & 33,215 & 395 \\
\hline myriads & 5 & 5 & muchos & 17,371 & 391 \\
\hline oodles & 13 & 13 & multitud & 1,387 & 311 \\
\hline pile & 706 & 256 & porrillo & 10 & 10 \\
\hline piles & 221 & 143 & porrón & 46 & 41 \\
\hline plenty & 2,609 & 347 & sinfín & 251 & 154 \\
\hline pots & 524 & 227 & suma & 2,355 & 342 \\
\hline stack & 280 & 165 & sumo & 622 & 244 \\
\hline stacks & 94 & 76 & tela & 1,084 & 292 \\
\hline \multirow[t]{2}{*}{ tons } & 478 & 218 & tropel & 120 & 92 \\
\hline & & & tutiplén & 10 & 10 \\
\hline
\end{tabular}

Proportional paucal quantifiers express a low amount, lower than the assumed norm.

TABLE 5

Selection of paucal quantifiers in English and Spanish

\begin{tabular}{|lrr||lrr|}
\hline $\begin{array}{l}\text { English paucal } \\
\text { quantifiers }\end{array}$ & Total ner. & Sample & $\begin{array}{l}\text { Spanish paucal } \\
\text { quantifiers }\end{array}$ & Total ner. & Sample \\
\hline bit & 15,713 & 390 & ápice & 175 & 122 \\
\hline few & 18,242 & 391 & miaja & 22 & 21 \\
\hline little & 22,947 & 393 & miga & 103 & 82 \\
\hline smattering & 33 & 31 & migaja & 18 & 17 \\
\hline smidge & 0 & 0 & pizca & 185 & 127 \\
\hline
\end{tabular}




\begin{tabular}{|c|c|c|c|c|c|}
\hline smidgen & 10 & 10 & poca & 2,114 & 336 \\
\hline smidgeon & 4 & 4 & pocas & 3,401 & 358 \\
\hline smidgin & 0 & 0 & poco & 34,252 & 395 \\
\hline sprinkling & 85 & 70 & pocos & 6,210 & 376 \\
\hline & & & poquísima & 16 & 15 \\
\hline & & & poquísimas & 24 & 23 \\
\hline & & & poquísimo & 55 & 48 \\
\hline & & & poquísimos & 30 & 28 \\
\hline & & & poquita & 42 & 38 \\
\hline & & & poquitas & 21 & 20 \\
\hline & & & poquitín & 81 & 68 \\
\hline & & & poquitita & 0 & 0 \\
\hline & & & poquititas & 0 & 0 \\
\hline & & & poquitito & 13 & 13 \\
\hline & & & poquititos & 0 & 0 \\
\hline & & & poquito & 1,556 & 318 \\
\hline & & & poquitos & 39 & 36 \\
\hline
\end{tabular}

Proportional relational quantifiers express an amount that is directly related to the upper and lower parts of the scale and also very closely linked to two other functions: excess and sufficiency. Thus, relational quantifiers do not express amounts that are large or small according to a proportional scale but on the basis of a particular need.

TABLE 6

Selection of relational quantifiers in English and Spanish

\begin{tabular}{|c|c|c|c|c|c|}
\hline $\begin{array}{l}\text { English relational } \\
\text { quantifiers }\end{array}$ & Total ner. & Sample & $\begin{array}{l}\text { Spanish relational } \\
\text { quantifiers }\end{array}$ & Total ner. & Sample \\
\hline Enough & 13,705 & 389 & bastante & 8,798 & 383 \\
\hline & & & bastantes & 1,131 & 296 \\
\hline & & & demasiada & 758 & 262 \\
\hline & & & demasiadas & 596 & 240 \\
\hline & & & demasiado & 8,580 & 382 \\
\hline & & & demasiados & 578 & 237 \\
\hline & & & suficiente & 4,812 & 369 \\
\hline & & & suficientes & 1,522 & 317 \\
\hline
\end{tabular}

Relative quantifiers express a type of quantity either unknown, as is the case of the interrogative pronouns, or indefinite, as is the case with the forms ending in -ever, e.g. whatever, or -quier/a, e.g. cualquier. Another reason to name this group relative is the fact that these quantifiers very often precede comparative, consecutive or relative clauses (tanto... como, tanto... que, tanto... cuanto), which means that the amount expressed has been made relative by a clause that acts as a yardstick to measure that amount. Furthermore, they are relative quantifiers because the amount expressed is usually non-factual or non-assertive as is the case with any and its compounds. The amount of a certain entity or substance depends on its previous existence so 
there is an allusion to that amount, leaving, at the same time, traces of doubt as to whether that entity exists at all.

TABLE 7

Selection of relative quantifiers in English and Spanish

\begin{tabular}{|c|c|c|c|c|c|}
\hline $\begin{array}{l}\text { English relative } \\
\text { quantifiers }\end{array}$ & Total ner. & Sample & $\begin{array}{l}\text { Spanish relative } \\
\text { quantifiers }\end{array}$ & Total ner. & Sample \\
\hline any & 44,498 & 396 & cualesquiera & 205 & 136 \\
\hline anybody & 3,287 & 357 & cualquier & 17,599 & 391 \\
\hline anyhow & 202 & 134 & cualquiera & 3,420 & 358 \\
\hline anymore & 268 & 161 & cuanta & 116 & 90 \\
\hline anyone & 6,479 & 377 & cuánta & 169 & 119 \\
\hline anyplace & 6 & 6 & cuantas & 977 & 284 \\
\hline anything & 14,202 & 389 & cuántas & 524 & 227 \\
\hline anytime & 100 & 80 & cuanto & 13,305 & 388 \\
\hline anyway & 5,543 & 373 & cuánto & 1,371 & 310 \\
\hline anywhere & 1,977 & 333 & cuantos & 1,808 & 328 \\
\hline either & 8,374 & 382 & cuántos & 736 & 259 \\
\hline whatever & 6,283 & 376 & quienquiera & 40 & 36 \\
\hline whatnot & 108 & 85 & tanta & 3,297 & 357 \\
\hline whatsoever & 441 & 210 & tantas & 3,483 & 359 \\
\hline whichever & 360 & 190 & tanto & 33,927 & 395 \\
\hline whoever & 716 & 257 & tantos & 4,069 & 364 \\
\hline whosoever & 5 & 5 & & & \\
\hline
\end{tabular}

Those quantifiers with fewer than 10 occurrences were not included in the study, which left 188 word forms to be studied, 78 of which were English and 110 Spanish. The reason for the higher rate in Spanish is mainly its morphological richness sometimes one lexeme has four, five or even more word forms (poco has seventeen). The total number of concordances to be analysed amounted to 48,875 (21,491 of which were English and 27,384 Spanish).

\subsection{Process of description}

Once we knew which quantifiers we would take and how many concordances of each quantifier we would study, the descriptive phase started, with the following steps:

A) Locate the necessary concordances for each quantifier from the Bank of English of Cobuild and from CREA over the Internet. ${ }^{3}$

B) Classify each of the concordances from a functional point of view and tag each one manually according to the taxonomic category given.

C) Elaborate tables to present all the results, one for each quantifier. These tables cannot be reproduced here due to lack of space but they consist of a first column of functions, a second column of collocational patterns, a third column with the code assigned to each of the concordances that have that function and pattern (a number for the function and a letter for the pattern), a forth column that shows the number of occurrences of the quantifier in question with that function and that pattern and a fifth column that shows the 
percentage of that particular use with regard to the total number of cases studied. The uses are explained and illustrated with selected concordances after each table.

As regards point A it is important to explain that the line of concordance was taken as the unit of study because it corresponds approximately to an utterance. In functional grammar, the minimum unit to study is the utterance: "The utterance is the basic speech unit which in our view, should be the object of analysis in functional grammar" (Bondarko 1991:37-8), “The primary data against which hypotheses are to be tested are utterances, instances of language use" (Chesterman 1998:54).

In my view, the advantages of taking the utterance as the work unit are that a) it is large enough to comprise the textual environment necessary to analyse the behaviour of quantifiers and b) it is compact and manageable enough to make a semantic contrast that does not include matters of discourse analysis.

However, the extent of a line of concordance is not fixed and it is not always the case that a line of concordance corresponds to an utterance. Larger or shorter chunks of text were taken according to our needs. Cobuild's corpus allows users to choose an exact number of characters for each line of concordance; however CREA only gives two options. As we chose the smallest format, we got 50 characters on each side of the node. The number of characters chosen for the English concordances was then 120, a similar size. However, during the process of observation and classification of the concordances, it was noted that sometimes the given co-text was not enough to determine the function of the quantifier. Thus, it was necessary to resort back to CREA or COBUILD and take a larger chunk of text for that particular concordance.

As for point C, a table of an English quantifier is presented below by way of example.

TABLE 8

Description of the English proportional multal quantifier 'much.'

MUCH

\begin{tabular}{|c|c|c|c|c|}
\hline Functions & Collocational patterns & Code & Occurrences & Percentage \\
\hline \multirow{2}{*}{$\begin{array}{l}\text { Proportional multal } \\
\text { quantification }\end{array}$} & much + non-count noun & $1 a$ & 25 & $6,31 \%$ \\
\hline & much (as a pronoun) & $1 b$ & 23 & $5,8 \%$ \\
\hline Partition & much of & 2 & 16 & $4,04 \%$ \\
\hline \multirow[t]{6}{*}{ Intensification } & so much & $3 a$ & 40 & $10,1 \%$ \\
\hline & pretty much & $3 b$ & 5 & $1,26 \%$ \\
\hline & that much & $3 c$ & 7 & $1,76 \%$ \\
\hline & very much & $3 d$ & 5 & $1,26 \%$ \\
\hline & how much & $3 e$ & 3 & $0,75 \%$ \\
\hline & much much & $3 f$ & 1 & $0,25 \%$ \\
\hline \multirow[t]{4}{*}{ Degree } & $\begin{array}{l}(\text { aux. })+\text { much }+ \text { verb/verb } \\
+(\text { direct object })+\text { much }\end{array}$ & $4 a$ & 17 & $4,29 \%$ \\
\hline & $\begin{array}{l}\text { much }+ \text { adjectivel } \\
\text { comparative adverb }\end{array}$ & $4 b$ & 70 & $17,67 \%$ \\
\hline & much + prepositional phrase & $4 c$ & 3 & $0,75 \%$ \\
\hline & much to + genitive case & $4 d$ & 3 & $0,75 \%$ \\
\hline
\end{tabular}




\begin{tabular}{|c|c|c|c|c|}
\hline \multirow{2}{*}{ Excess } & too much & $5 a$ & 32 & $8,08 \%$ \\
\hline & a bit much & $5 b$ & 2 & $0,5 \%$ \\
\hline \multirow{2}{*}{ Additive quantification } & much more + (noun) & $6 a$ & 12 & $3,03 \%$ \\
\hline & much else & $6 b$ & 1 & $0,25 \%$ \\
\hline $\begin{array}{l}\text { Relative comparative } \\
\text { quantification }\end{array}$ & so /as much (... as) & 7 & 24 & $6,06 \%$ \\
\hline Qualification & $\begin{array}{l}\text { much }+ \text { past participle } \\
\text { (as a prefix) }\end{array}$ & 8 & 12 & $3,03 \%$ \\
\hline \multirow{5}{*}{ Approximation } & much the same & $9 a$ & 5 & $1,26 \%$ \\
\hline & much like & $9 b$ & 1 & $0,25 \%$ \\
\hline & to be very much + complement & $9 c$ & 7 & $1,76 \%$ \\
\hline & very much so & $9 d$ & 1 & $0,25 \%$ \\
\hline & much as + subject + auxiliary & $9 e$ & 1 & $0,25 \%$ \\
\hline \multirow[t]{3}{*}{ Attenuation } & not ... much of $a$ & $10 a$ & 5 & $1,26 \%$ \\
\hline & nothing /anything much & $10 b$ & 2 & $0,5 \%$ \\
\hline & not much & $10 c$ & 5 & $1,26 \%$ \\
\hline $\begin{array}{l}\text { Relative interrogative } \\
\text { quantification }\end{array}$ & how much & 11 & 31 & $7,82 \%$ \\
\hline $\begin{array}{l}\text { Precise multiplier } \\
\text { quantification }\end{array}$ & twice as much & 12 & 1 & $0,25 \%$ \\
\hline Frequency & $\begin{array}{l}\text { much }+ \text { past participle / } \\
\text { verb }+ \text { much }\end{array}$ & 13 & 4 & $1,01 \%$ \\
\hline \multirow[t]{5}{*}{ Emphasis } & as much as + numeral & $14 a$ & 2 & $0,5 \%$ \\
\hline & much too & $14 b$ & 3 & $0,75 \%$ \\
\hline & much at all & $14 c$ & 1 & $0,25 \%$ \\
\hline & much less...! & $14 d$ & 1 & $0,25 \%$ \\
\hline & $\begin{array}{l}\text { so much as }+ \text { verb in non- } \\
\text { assertive context }\end{array}$ & $14 e$ & 2 & $0,5 \%$ \\
\hline Politeness & thank you / thanks very much & 15 & 12 & $3,03 \%$ \\
\hline Exaltation & think much of & 16 & 1 & $0,25 \%$ \\
\hline $\begin{array}{l}\text { Classificatory } \\
\text { quantification }\end{array}$ & much + singular count noun & 17 & 1 & $0,25 \%$ \\
\hline \multirow[t]{3}{*}{ Concession } & however much & $18 a$ & 1 & $0,25 \%$ \\
\hline & much as & $18 b$ & 1 & $0,25 \%$ \\
\hline & no matter how much & $18 c$ & 2 & $0,5 \%$ \\
\hline $\begin{array}{l}\text { Universal quantification } \\
\text { of entirety }\end{array}$ & as much as possible & 19 & 4 & $1,01 \%$ \\
\hline Idiomatic uses & no much point + gerund & 20 & 1 & $0,25 \%$ \\
\hline Total & & & 396 & $100 \%$ \\
\hline
\end{tabular}

Much expresses porportional multal quantification both as a determiner, as in example 1 and as a pronoun, example 2:

(1) "History reveals much volatility in the run-up to national elections"

(2) "the ideas and plans he develops now will do much to help his prospects in the next few years." 
It can also indicate a large part of a whole, that is, partition, as in example 3.

(3) "Brittle agrees with much of the commission report."

A third function is that of intensification, realised by means of the following collocations: so (example 4), pretty (example 5), that (example 6), very (example 7) and how plus much (example 8) or by means of the repetition of much (example 9).

(4) "Why am I making idle chatter when there is so much I want to say?"

(5) "I pretty much set the pace myself of what I want to do"

(6) "we never had that much money"

(7) "the students really don't have very much to say"

(8) "I phoned up to say how much I enjoy your programme"

(9) "But the rift in the Brosnan clan goes back much much further."

Much can also modify a verb, as in example 10, an adjective, as in 11 , an adverb, a prepositional phrase, as in 12 , or the preposition to plus a possessive structure, as in 13. The function is then of degree:

(10) "Nicola Rescigno, a conductor once much favoured by Callas, provides solid accompaniment"

(11) "Completing the Profit Forecast will give you a much clearer view of how your business will develop"

(12) "the odds will be very much in our favour"

(13) "And against her solicitor's advice - but much to Steve's delight - Kim decides to invest in Steve's business."

Another of the uses of much is excess, as examples 14 and 15 show:

(14) "Maybe people expected too much too soon but we must listen to the fans"

(15) "you have to pay for the glasses that they give your children. So thought that was a bit much didn't we? Yeah. But he's got to wear them so..."

Additive quantification appears in utterances like 16 and 17:

(16) "systems are simple to install and can do much more than give water a cleaner and fresher taste"

(17) "Like much else at Cap Esterel, activities for children are not cheap but they are superbly organised.”

Qualification is another of its functions; in 9 out of the 12 occurrences it is followed by a hyphen, taking part of a compound that characterises the head of the noun phrase where it belongs, as in example 18.

(18) "Sharon managed to get two nights of much-needed rest. Then came her date with Travis.”

There are some cases of comparative quantification, like example 19 and several expressions made up with much which have an approximative or vague function, like examples 20, 21, 22, 23 and 24.

(19) "he was convinced the world needed perestroika as much as the Soviet people did"

(20) "You will begin to look at her in much the same way that Daddy Alien regarded John Hurt"

(21) “...with a vertical design of chained links, much like the one on the stone roadside shelter” 
(22) "his sympathy was very much with nature you see"

(23) "- I suppose this was like your probably your first time as a sort of independent er person. - Oh yes. Very much so"

(24) "It is exceptional also for looking much as it did in the 18th century."

Attenuation is achieved by three ways, as shown in examples 25, 26 and 27.

(25) "I was over the moon, if that's not too much of a cliché"

(26) "We very rarely had anything much to do"

(27) "Not much can beat driving across rugged terrain"

Relative interrogative quantification, as shown in example 28, refers to an unknown amount, which needn't to be large.

(28) "I can't actually say how much everything costs and where we could make savings."

Unlike the other types of quantification present in the use of much, which are imprecise, precise multiplier quantification expresses a precise amount, which is double another amount previously mentioned or known by the speaker and the hearer. We know that it is exactly double that other amount thanks to the collocate twice, e.g.

(29) "He cost twice as much and has done well for me lately."

Frequency is a function that may be confused with degree as the formal structure is similar in some cases (verb plus much or much plus past participle); however, the difference is clearly seen in example 30 , where much does not allude to the amount of colour or the force of the painting but to how often the Seine was painted by the Impressionists.

(30) "It is held on the Chatou island in the Seine (much painted in its time by the Impressionists)."

There are several ways of emphasising using the word much, as is shown in examples 31, 32, 33, 34 and 35.

(31) "The Bill will be as much as $\$ 200,000 "$

(32) "The counsellor said Perhaps it feels much too frightening and too vulnerable to be nice and loving"

(33) "We don't really know much at all at the moment"

(34) "Anton helps you perform the miracles you never thought you could make in a day, much less in thirty minutes!"

(35) "She recently hosted a dinner party for 16 with her husband, Clive Jones, and didn't so much as scrape a carrot. 'I served the dinner from Waitrose."

Much occurs quite often in an expression of politeness: thanks very much or thank you very much, as in 36.

(36) "thanks very much and have a good journey back home afterwards."

Another function is that of exaltation, as in example 37, where much is used with the verb think. Much here does not indicate the frequency or the intensity of the thoughts but how highly something or someone is regarded.

(37) "He had never thought much of highbrow music or the people who made it." 
Classificatory quantification is expressed by means of a singular count noun preceded by much, as in example 38, instead of the use of many and a plural form of that noun, which is the normal expression of proportional multal quantification. It is classificatory because the focus is not on the plurality of elements but on underlying that they are elements that belong to the same class.

(38) "Tell base all OK, but much kit lost. Do not release to press."

Concession is expressed with the following patterns: however much (example 39), much as (example 40) and no matter how much (example 41).

(39) "However much we might miss being able to slide into a Miss Selfridge size 10 (the smallest in the universe in my experience) most women over the age of 35 do not feel remotely wistful about their teens or twenties"

(40) "Much as I hate to have to say it I can't see anyone quite good enough to lift Maradona's crown"

(41) "I'd gotten to a stage no matter how much success we had or the more success we had not just in playing terms but in commercial terms building a new stadium the bigger the obstacles were becoming."

Much can express a typical function of another group of quantifiers, universal quantification of entirety, in those cases where it is followed by as possible, because the underlying implicature here is that as much as possible means all that is possible, as in example 42.

(42) "I want to make as much money in as little time as possible."

Finally, there is an idiomatic expression that shows the uselessness of something, as shown in example 43.

(43) “I mean there's not much point being Queen if you can't abdicate when you want to."

\subsection{Process of juxtaposition}

After having completed a full description of the behaviour of all the English and Spanish quantifiers, observing and classifying all their occurrences in our corpus of samples, the research became onomasiological again as we proceeded from the functions at this stage. The steps are the following:

A) Observe all the functions found during the process of description and distinguish those that are closely related to quantification from those that lack a quantifying meaning.

B) Group the quantifiers into their respective families and specify which functions are found for each family.

C) Present the collocational patterns of the quantifiers belonging to the same group that express the same function in a table, in a juxtaposed manner, that is, matching the equivalent expressions. The tables of the quantifying functions are first presented; secondly, the tables of the non-quantifying functions. This process is repeated for each of the groups of quantifiers.

It is necessary to explain something about point C. In those cases where no interlinguistic equivalent was found in the corpus, ${ }^{4}$ we suggested a functional equivalent, in italics, for the sake of clarity and in order to help the reader see the meaning of the expression in the other language. They are only some of the possible 
translations and they do not represent any prescriptive motivations. As an example of the results of this process we offer the juxtaposition of patterns of the multal quantifiers expressing intensification.

TABLE 9

Juxtaposition of the patterns of the proportional multal quantifiers expressing intensification

so much, that much

how much

pretty much

much much

very much

so many, that many

many many (many) (many)

how many

a whole lot, quite a lot, a hell of a lot,

an awful lot, a heck of a lot, such a lot,

lots and lots

a whole/ vast/ fair/ awful/ big load,

whole stack, stacks and stacks,

a whole/ colossal/ what a heap,

such a mass, masses and masses,

a great/ big/ large/ high/ huge/ whole pile, piles and piles, enormous/ large/ whole/ great piles, loads and loads, loads of loads, loads loads, bags and bags, bags of bags, good bags

a very good/ great deal, a lot great deal

extreme/ great + noun

extremely important tanto/a (como eso)

cuánto/a

bastante

pero mucho mucho, y mucho, mucha mucha

muy mucho

tantos/as (como eso)

muchos/as muchos/as muchos/as

cuántos/as

muchísimo/a/os/as (+ noun), tal cantidades de

un buen/ enorme/ gran montón, montón exorbitante, qué mogollón, un buen mogollón

tal/ qué/ tanta cantidad

sumo/a + noun

(de) suma importancia

Intensification does not differ much from proportional multal quantification; in fact it is the same but magnified. This function is generally expressed by adding intensifiers to the multal quantifiers in English, e.g. so/ that/ how/ pretty much, a whole/ quite/ a hell of/ an awful/ a heck of a lot, and this is a resource also used in Spanish, which nevertheless shows a preference for the use of suffixes, e.g. muchisimo/a/os/as (+ noun) or the use of other quantifiers belonging to other families, relative or relational e.g. tanto/a, bastante.

\subsection{Process of contrast}

Finally, all the information obtained in the previous phases is contrasted in the two languages. By way of example, let us present one of the final tables comprising the patterns of the indefinite quantifiers that are the means of expression of one of the functions found, exaltation: 
TABLE 10

Contrast of the patterns of the English and Spanish indefinite quantifiers used to express exaltation

\begin{tabular}{|c|c|c|c|c|}
\hline \multirow[t]{2}{*}{$\begin{array}{l}\text { second to none } \\
\text { none other than } \\
\text { nothing less than } \\
\text { nothing like } \\
\text { nothing so/ as + adj. + as } \\
\text { nothing to compare } \\
\text { nowhere [in comparative } \\
\text { clauses with inversion] } \\
\text { nowhere [in inversion] } \\
\text { nowhere [in comparative } \\
\text { clauses] }\end{array}$} & Negative & \multirow[t]{7}{*}{ 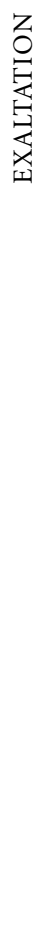 } & Negative & $\begin{array}{l}\text { na menos que } \\
\text { (nada más y) nada menos que }\end{array}$ \\
\hline & Universal & & Universal & todo un \\
\hline $\begin{array}{l}\text { no other... + so many } \\
\text { to be (a) somebody } \\
\text { quite (a) something }\end{array}$ & Existential & & Existential & $\begin{array}{l}\text { algo más que } \\
\text { ser alguien }\end{array}$ \\
\hline \multirow[t]{4}{*}{ think much of } & Multal & & Multal & $\begin{array}{l}\text { la nada desdeñable cantidad } \\
\text { ser mucho más que }\end{array}$ \\
\hline & Paucal & & Paucal & $\begin{array}{l}\text { no poca } \\
\text { no... poca } \\
\text { no pocas } \\
\text { no poco } \\
\text { no pocos }\end{array}$ \\
\hline & Relational & & Relational & bastante más que \\
\hline & Relative & & Relative & \\
\hline
\end{tabular}

Some of the concordances that were classified under this heading were: “... and a new live version of "Nothing Compares 2 U," "However, nowhere are application forms used as widely as in the UK," "No other ancient continent inspires so many questions," "and a second-billed Sean Penn (all side-burns, spectacles and fast talk) is really quite something to see (an Oscar nomination, surely?)," "Hoy luchará por ser el mejor español nada más y nada menos que frente a su ídolo, Carlos Sainz," "el primer día de 16 millones de espectadores: todo un récord," “...las razones que convierten la visita de Aznar en algo más que otro viaje," "Ciertamente, no son pocos los peligros que se ciernen sobre este parque," "Bernie es bastante más que una simple comedia."

The interlinguistic contrast shows the most common resources to express each of the functions in each language and also which functions are expressed by means of indefinite quantifiers in both languages and which make use of these quantifiers only in one language. Of the 56 functions found, 33 are quantifying and 23 nonquantifying, which shows the variety of uses of the English and Spanish quantifiers and the fact that they are not always used to express quantification. However, in $76.59 \%$ of the times the English quantifiers are used, they have a fully quantifying function and in Spanish, the percentage is even slightly higher, 79.84\%. Although it is also true that some of the selected terms never proved to have a quantifying function, as we suspected at first, they were nonetheless included in the study because they were formally related to the other terms and felt to be part of the same paradigm, as 
is the case of everyday and anyway, for example. Some quantifiers have been reported to have a wide range of different uses, e.g. much, has 20 functions, nada, otro and poco, 16, and all and mucho, 15, whereas others are monofunctional, e.g. someday, whatnot, ambos, ambas, porrillo, poquisimas and poquitas. On the other hand, some functions are expressed by means of a large number of resources in one language or both - emphasis, additive quantification and approximation are those that have the largest number of patterns in English and emphasis, intensification and additive quantification in Spanish, which shows a great deal of similarity - whereas other functions do not have a very rich expression, e.g. inminence is only expressed by one pattern in Spanish, por poco and none in English.

\section{Conclusion}

The method that has been presented and advocated here seems to work in descriptive and functional contrastive studies that are based on empirical research, especially using comparable corpora. The advantage of this four-staged method is the independence of the partial results after each process, which serve different purposes in foreign language teaching or translation training. The idea behind this is that the difficulty of translating or learning a foreign language is not to learn a few words, for example these 188 quantifiers, but to learn what they mean in different environments and how they can be used to express different meanings as compared to the resources of one's mother tongue. The final conclusion of this paper is that the fourstaged method presented here, which is based on the data from two monolingual corpora of two different languages, provides a suitable way of studying semantic fields contrastively in pairs of languages.

\section{NOTES}

1. See http://titania.cobuild.collins.co.uk/

2. CREA is the official Reference Corpus of Contemporary Spanish built by the Spanish Royal Academy. See http://www.rae.es/

3. A registration was previously required, free in the case of CREA. I am very grateful to both Cobuild and RAE for access to their respective corpora.

4. It is obvious that quantifiers, or any other elements of other paradigms, are sometimes best translated by other expressions that are not made up of quantifiers in another language or they are quantifiers belonging to other groups.

\section{REFERENCES}

Aijmer, K., Altenberg, B. and M. Johansson (eds.). (1996): Languages in Contrast. Papers from a Symposium on Text-based Cross-linguistics Studies, Lund 4-5 March 1994, Lund, Lund University Press.

Alarcos, E. (1982): Estudios de gramática funcional del español, Madrid: Gredos.

Alarcos, E. (1994): Gramática de la lengua española, Madrid, Espasa Calpe.

Bello, A. (1981): Gramática de la lengua castellana, Tenerife, Instituto Universitario de Lingüística.

Berry, R. (1997): Determiners and Quantifiers, Glasgow, Collins Cobuild.

Biber, D., Johansson, S., Leech, G. Conrad, S. and E. Finegan (1999): Longman Grammar of Spoken and Written English, London, Longman.

Bloomfield, L. (1933): Language, London, Allen \& Unwin. 
Bondarko, A. V. (1991): Functional Grammar. A Field Approach, Amsterdam/Philadelphia, Benjamins.

Bosque, I. and V. Demonte (eds.) (1999): Gramática descriptiva de la lengua española, Madrid, Espasa.

CATford, J. (1965): A Linguistic Theory of Translation, London, O.U.P.

Chesterman, A. (1998): Contrastive Functional Analysis. Amsterdam/ Philadelphia, Benjamins.

Chitoran, D. (ed.) (1976): Second International Conference of English Contrastive Projects. Bucharest, University Press.

Сномsкy, N. (1957): Syntactic Structures. The Hague, Mouton de Gruyter.

Dik, S.C. (1978): Functional Grammar. Amsterdam, North Holland.

Di Pietro, R. J. (1971): Language Structures in Contrast, Rowley, Mass, Newbury.

Downing, A. and P. LOCKE (1992): A University Course in English Grammar, New York/London, Prentice-Hall International.

Filipovic, R. (ed.) (1970): Reports and Studies, Yugoslav Serbo-Croatian-English Contrastive Project. Zagreb, Institute of Linguistics.

Fillmore, C. (1968): “The Case for Case," Universals in Linguistic Theory edited by E. BaCH \& R. T. Harms (eds.), New York, Holt, Rinehart \& Winston, pp. 1-90.

FisiaK, J. (ed.). (1973-onwards): Papers and Studies in Contrastive Linguistics, Poznan, Mickiewicz.

FrIEs, C. (1945): Teaching and Learning English as a Foreign Language, Ann Arbor, University of Michigan Press.

Halliday, M. (1980): "Language Structure and Language Function," New Horizons in Linguistics 1 edited by J. Lyons (ed.). Harmondsworth, Penguin, pp. 140-167.

Halliday, M. (1985/ 1994): An Introduction to Functional Grammar. 2nd edition. London, Arnold.

Halliday, M. and R. Hasan (1976): Cohesion in English, London/ New York, Longman.

Halliday, M. and R. Hasan (1989): Language, Context and Text: Aspects of Language in a SocialSemiotic Perspective, Oxford, OUP.

James, C. (1980): Contrastive Analysis, Singapore, Longman.

Jaszczolt, K. and K. Turner (1996): Contrastive Semantics and Pragmatics. Meanings and Representations, Vol. I Oxford, Pergamon.

Jaszczolt, K. and K. Turner (1996): Contrastive Semantics and Pragmatics. Discourse Strategies, Vol. II Oxford, Pergamon.

Johansson, S. (1998): “On Computer Corpora in Contrastive Linguistics," Compare or Contrast? Current Issues in Cross-Language Research edited by W.R Cooper (ed.) Tampere (Finland), University of Tampere, pp. 269-289.

Johansson, S. and S. Oksefjell (eds.) (1998): Corpora and Cross-Linguistic Research. Theory, Method and Case Studies, Amsterdam/ Atlanta, Rodopi.

Krzeszowski, T. P. (1971): "Equivalence, Congruence and Deep Structure," Papers in Contrastive Linguistics edited by G. Nickel (ed.) Cambridge, CAP, pp. 37-48.

Krzeszowski, T. P. (1979): Contrastive Generative Grammar: Theoretical Foundations, Tübingen, Narr.

Krzeszowski, T. P. (1990): Contrasting Languages. The Scope of Contrastive Linguistics. Berlin/ New York, Mouton de Gruyter.

Labrador de la Cruz, B. (2000): Estudio contrastivo de la cuantificación inglés-español, Doctoral thesis, León, Universidad de León.

Lado, R. (1957): Linguistics across Cultures. Michigan, University of Michigan.

LounivaARA, S. (1998): "Aspects of Adverb Position in some Finish and English Texts," Compare or Contrast? Current Issues in Cross-Language Research edited by W.R Cooper (ed.) Tampere (Finland), University of Tampere, pp. 145-157

Matte Bonn, F. (1995): Gramática comunicativa del español, I \& II, Madrid, Edelsa.

McEnery, T. and M. OAkes (1996): "Sentence Alignment in the CRATER Project," Using Corpora for Language Research edited by J. Тномаs et al. (eds.) London/ New York, Longman, pp. 211232 . 
Neubert, A. (1985): Text and Translation, Leipzig, Enzyklopädie.

Neubert, A. and G. M. Shreve (1992): Translation as Text. Kent, Ohio, The Kent State University Press.

NidA, E. A. (1964): Toward a Science of Translating. Leiden, Brill.

Quirk, R., Greenbaum, S., Leech, G. and J. Svartvik (1985/1989): A Comprehensive Grammar of the English Language, New York, Longman.

Reiss, K. und H.J. Vermeer (1984): Grundlegung einer allgemeinen Translationstheorie, Tübingen, Niemeyer.

SAlkie, R. (1997): "Naturalness and Contrastive Linguistics," Proceedings of PALC '97 edited by B. Lewandowska-Tomaszczyk \& P.J. Melia (eds.), Lodz, University of Lodz, pp. 297-312.

Salkie, R., Aijmer, K. and M. Barlow (eds.) (1999-onwards): Languages in Contrast. International Journal for Contrastive Linguistics, Amsterdam/ Philadelphia, Benjamins.

Saussure, F. (1966): Course in General Linguistics, New York, McGraw \& Hill.

Sinclair, J. (1991): Corpus, Concordance, Collocation, Hong Kong, OUP.

Toury, G. (1980): In Search of a Theory of Translation, Tel Aviv, Porter Institute for Poetics and Semiotics.

Toury, G. (1995): Descriptive Translation Studies and Beyond, Amsterdam/ Philadelphia, Benjamins. Whorf, B.L. (1941): Technology Review, Cambribge, MA, MIT reedited in J.B. Carroll (ed). (1956): Language, Thought and Reality, Cambribge, MA: MIT. 